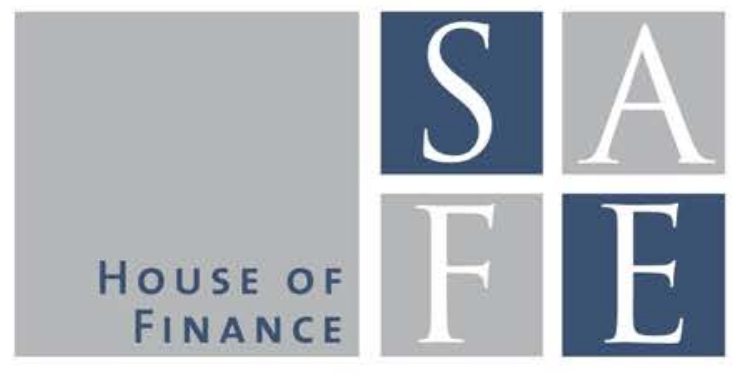

WORKING PAPER SERIES

Baptiste Massenot - Yuri Pettinicchi

\title{
Can Firms see into the Future? Survey evidence from Germany
}

SAFE Working Paper No. 187

SAFE I Sustainable Architecture for Finance in Europe

A cooperation of the Center for Financial Studies and Goethe University Frankfurt 


\section{Non-Technical Summary}

This paper presents new evidence on the expectation formation process of firms from a survey of the German manufacturing sector. It focuses on the expectation about their future business conditions, which enters the widely followed economic sentiment index and which is an important determinant of their employment and investment decisions. Do firms make errors when predicting their future business? Overoptimistic firms may hire or invest too much, thus reducing their profits. Are these expectation errors predictable? Do they depend on experience? If firms tend to over-extrapolate their experience, they might all become over-pessimistic during a crisis, thus delaying a recovery.

A striking observation in our view is that when looking at the evolution of expected and realized business conditions, the two variables closely follow each other. First, it suggests that firms have a limited ability to forecast their future. Otherwise, we would observe that expected business lags realized business by the forecasting horizon, which is 6 months in the data we use. Second, it suggests that firms make predictable forecast errors. For example, firms will become overoptimistic following an improvement in their business.

To further examine these conjectures, we compute for each firm a measure of expectation error by taking the difference between its expected business and its future realized business. If the expectation error is positive (negative), the firm is over-optimistic (over-pessimistic). We find that expectation errors are positively correlated with past business activity. This confirms that firms extrapolate their experience too much and make predictable forecasting errors. This result is robust to a variety of specifications. It also holds for changes in business experienced further in the past and after controlling for time fixed effects or different macroeconomic variables. Finally, firms extrapolate negative past business more than positive ones.

Over-extrapolation may amplify business cycles. We look at expectations and expectation errors more specifically around business cycle peaks and troughs. We find that firms are unusually optimistic just before a downturn and unusually pessimistic just before a recovery. This implies that firms do not seem to anticipate the upcoming reversals and that cycles may be amplified if expectations are followed by changes in investment or employment.

To further study whether firms can anticipate reversals, we study the German reunification period because it gives us more information about some of the shocks experienced by firms. In the context of a global recession, the reunification provided West German manufacturers with a large exogenous positive shock to their demand. The reason is that East Germans started to import the often better West German products. However, different industries were affected differently. Industries producing necessity goods such as food experienced a boom. By contrast, industries producing more expensive and less necessary goods such as new cars benefited less or not at all from the reunification since East Germans could not afford them. We find that all industries extrapolated the initial negative trend and thus that industries experiencing the largest positive shock failed to anticipate these changes.

Next, we study whether the types of shocks that firms try to forecast look more like supply or demand shocks. In most cases, firms that expect their sales to move in one direction also expect 
their prices to move in the same direction. This suggests that firms mostly forecast demand shocks.

If firms have trouble forecasting their business activity, they may fail to adjust investment or employment to their efficient level, which would affect their inventories and profits. Overoptimistic firms subsequently report larger inventories and lower profits, suggesting that firms increased their production scale too much. By contrast, overpessimistic firms subsequently report lower inventories and larger profits. While the larger profits look like a positive consequence, the lower inventories suggest that negative expectation errors entail opportunity costs and that firms fail to scale up enough their production.

If expectation errors are costly, firms may learn how to reduce their extrapolation bias over time. Larger firms may also have more resources available for forecasting and thus have a smaller extrapolation bias. We indeed find that the impact of experience on expectation errors decreases with the age and the size of the firm. However, our estimates suggest that it would take more than 7 centuries for the extrapolation bias to be eliminated. A large firm (more than 250 employees) has an extrapolation bias that is about 10 to $25 \%$ smaller than the one of a small firm (less than 10 employees). 


\title{
Can firms see into the future? Survey evidence from Germany*
}

\author{
Baptiste Massenot $^{\dagger}$ Yuri Pettinicchi ${ }^{\ddagger}$
}

November 3, 2017

\section{Introduction}

This paper presents new evidence on the expectation formation process of firms from a survey of the German manufacturing sector. It focuses on the expectation about their future business conditions, which enters the widely followed economic sentiment index and which is an important determinant of their employment and investment decisions. ${ }^{1}$ Do firms make errors when predicting their future business? Overoptimistic firms may hire or invest too much, thus reducing their profits. Are these expectation errors predictable? Do they depend on experience? If firms tend to over-extrapolate their experience, they might all become over-pessimistic during a crisis, thus delaying a recovery.

Figure 1 shows the evolution of expected and realized business conditions. A striking observation in our view is that these two variables closely follow each other. First, it suggests that firms have a limited ability to forecast their future. Otherwise, we would observe that expected business lags realized business by the forecasting horizon, which is 6 months here. Second,

\footnotetext{
${ }^{*}$ We gratefully acknowledge research support from the Research Center SAFE, funded by the State of Hessen initiative for research LOEWE. Yuri Pettinicchi gratefully acknowledges funding received from the 7.FP, COFUND, Goethe International Postdoc Programme GO-IN, No. 291776. We thank participants of the IFO Conference on Macroeconomics and Survey Data (2016) for useful comments. We also thank Heike Mittelmeier and Shuyao Yang for help with the IFO dataset.

${ }^{\dagger}$ Goethe University Frankfurt - SAFE, E-mail: massenot@safe.uni-frankfurt.de.

${ }^{\ddagger}$ Max Planck Institute for Social Law and Social Policy, E-mail: pettinicchi@mea.mpisoc.mpg.de.

${ }^{1}$ Abberger and Wohlrabe (2006) discuss the forecasting properties of this index.
} 


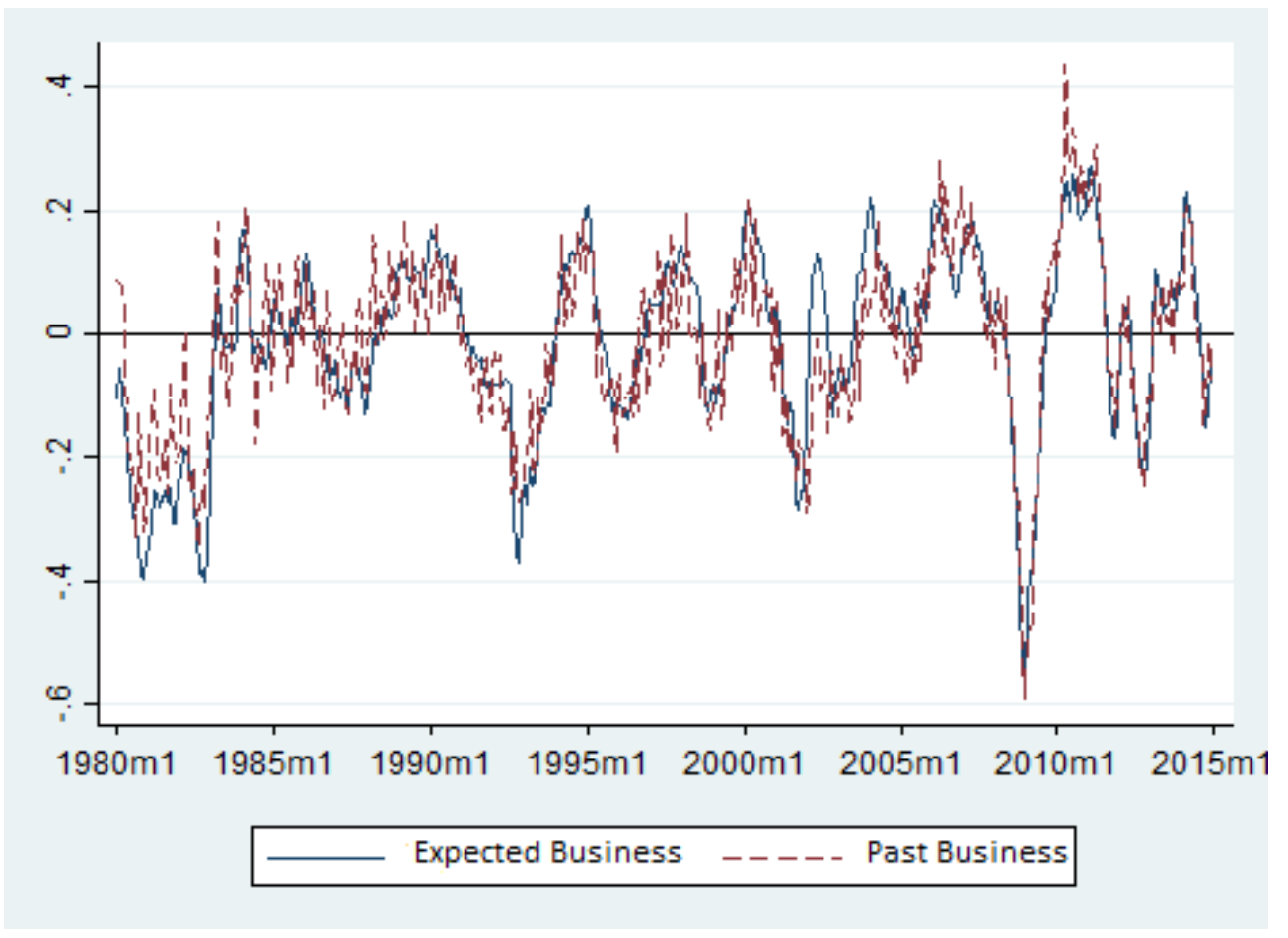

Figure 1: Evolution of expected and past business. Both variables range from -1 to 1 , where a higher value indicates a bigger improvement. See section 2 for further details.

it suggests that firms make predictable forecast errors. For example, firms will become overoptimistic following an improvement in their business.

To further examine these conjectures, we compute for each firm a measure of expectation error by taking the difference between its expected business and its future realized business. If the expectation error is positive (negative), the firm is over-optimistic (over-pessimistic). Figure 2 shows the evolution of these expectation errors. Firms seem to be overoptimistic just before recessions and overpessimistic during recessions. When analyzing the individual data, we find that expectation errors are indeed positively correlated with past business activity. This confirms that firms extrapolate their experience too much and make predictable forecasting errors. This result is robust to a variety of specifications. It also holds for changes in business experienced further in the past and after controlling for time fixed effects or different macroeconomic variables. Finally, firms extrapolate negative past business more than positive ones.

Over-extrapolation may amplify business cycles. We look at expectations and expectation er- 


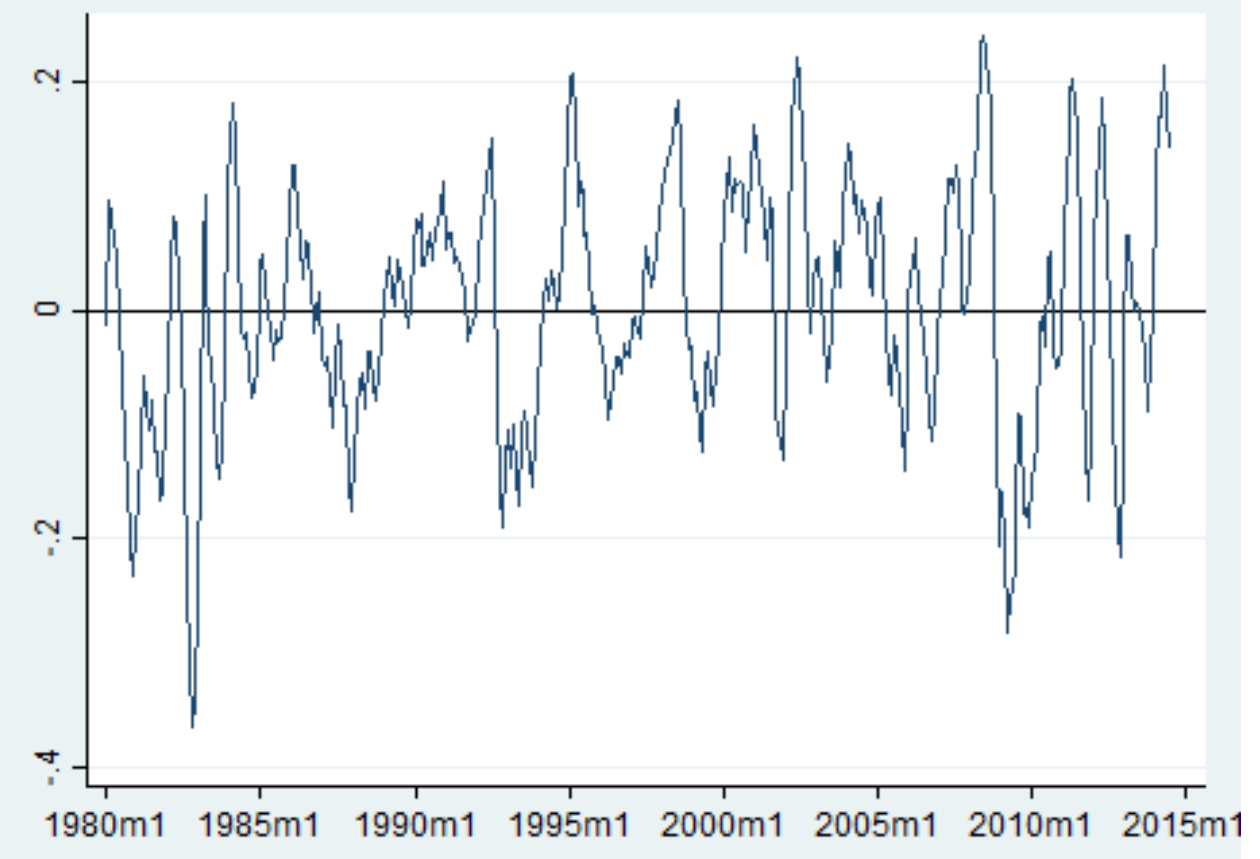

Figure 2: Evolution of expectation errors, computed as the difference between expected business activity and future realized business activity. See section 2 for further details.

rors more specifically around business cycle peaks and troughs. Figures 1 and 2 already suggest that firms are unusually optimistic just before a downturn and unusually pessimistic just before a recovery. We confirm this observation using regression analysis with the individual data. This implies that firms do not seem to anticipate the upcoming reversals and that cycles may be amplified if expectations are followed by changes in investment or employment.

To further study whether firms can anticipate reversals, we study the German reunification period because it gives us more information about some of the shocks experienced by firms. In the context of a global recession, the reunification provided West German manufacturers with a large exogenous positive shock to their demand. The reason is that East Germans started to import the often better West German products. However, different industries were affected differently. Industries producing necessity goods such as food experienced a boom. By contrast, industries producing more expensive and less necessary goods such as new cars benefited less or not at all from the reunification since East Germans could not afford them. We find that all 
industries extrapolated the initial negative trend and thus that industries experiencing the largest positive shock failed to anticipate these changes.

Next, we study whether the types of shocks that firms try to forecast look more like supply or demand shocks. In most cases, firms that expect their sales to move in one direction also expect their prices to move in the same direction. This suggests that firms mostly forecast demand shocks.

If firms have trouble forecasting their business activity, they may fail to adjust investment or employment to their efficient level, which would affect their inventories and profits. Overoptimistic firms subsequently report larger inventories and lower profits, suggesting that firms increased their production scale too much. By contrast, overpessimistic firms subsequently report lower inventories and larger profits. While the larger profits look like a positive consequence, the lower inventories suggest that negative expectation errors entail opportunity costs and that firms fail to scale up enough their production.

If expectation errors are costly, firms may learn how to reduce their extrapolation bias over time. Larger firms may also have more resources available for forecasting and thus have a smaller extrapolation bias. We indeed find that the impact of experience on expectation errors decreases with the age and the size of the firm. However, our estimates suggest that it would take more than 7 centuries for the extrapolation bias to be eliminated. A large firm (more than 250 employees) has an extrapolation bias that is about 10 to $25 \%$ smaller than the one of a small firm (less than 10 employees).

Why do firms fail to reduce their extrapolation bias? Maybe it would be too costly. A firm may have to spend time or resources to improve the accuracy of its expectations. Also, relying on intuition rather than reason may save cognitive resources (Kahneman, 2011). The literature proposes several behavioral foundations for extrapolative biases (Tversky and Kahneman, 1974; Gilovich et al., 1985; Rabin, 2002; Rabin and Vayanos, 2010).

Our paper is related to the empirical literature studying expectations using survey data (Man- 
ski, 2004; Pesaran and Weale, 2006). A few other references have used the same data as we do. Bachmann and Elstner (2015) quantify firms expectation errors and their consequences on welfare. Buchheim and Link (2017) show that firms only have a limited ability to forecast their future business conditions. Our work implies that this observation may in part result from overextrapolation. Triebs and Tumlinson (2016) study the accuracy of expectations of Eastern German firms following the reunification. Survey data on expectations has also been used to discriminate between different models of expectation formation under imperfect information (Coibion and Gorodnichenko, 2012; Andrade and Le Bihan, 2013; Coibion and Gorodnichenko, 2015; Coibion et al., 2015).

We contribute to the growing body of evidence supporting extrapolative expectations. The evidence comes from laboratory experiments (Haruvy et al., 2007; Asparouhova et al., 2009; Hommes et al., 2008; Beshears et al., 2013; Frydman and Nave, 2016) and survey data (Tortorice, 2012; Greenwood and Shleifer, 2014; Massenot and Pettinicchi, 2017). We suggest that overextrapolation is pervasive as it also applies to expectations formed by firms and about a variable more familiar than, say, inflation or asset prices. In a study of whether expectations about earnings growth matter for investment, Gennaioli et al. (2015) also report that expectations errors are positively correlated with past earnings growth. Finally, our evidence is in line with the growing evidence that experience plays a crucial role on economic behavior through its effect on expectations (Barberis et al., 1998; Vissing-Jorgensen, 2004; Piazzesi and Schneider, 2009; Malmendier and Nagel, 2011).

The paper is organized as follows. Section 2 presents the data. Section 3 investigates whether firms over-extrapolate. Section 4 studies whether firms anticipate reversals. Section 5 discusses further aspects of the expectation formation process. Section 6 concludes. 


\section{Data}

\subsection{The IFO Business Survey}

We use the IFO Business Survey of German manufacturing firms. It has been conducted on a monthly basis since 1980 (1990 for East Germany). The main purpose of the survey is to build the Business Climate Indicator, which is the reference measure of economic sentiment for policy makers, practitioners, and the general public in Germany and is now part of the EU-harmonized business sentiment index. Participation in the survey is voluntary. Firms are encouraged to participate by gaining early access to the Business Climate Indicator. The IFO Institute guarantees confidentiality so we can reasonably exclude any strategic behavior in answering the survey.

The unbalanced panel has about 1.5 million observations from about 20,000 survey participants. The number of participants has been declining over time, with about 5,000 participants in the 1980s versus 2,500 in the 2010s. We have on average about 96 observations per firm. To assess the representativeness of the survey, Tables 1 and 2 compare the distribution of firms by size and sector in the survey and in the whole German manufacturing sector. The survey underrepresents small firms and over represents large firms. The sectoral representativeness is good overall. The food sector is under-represented while the wood sector is over-represented.

Table 1: Distribution of firms by size (2013)

\begin{tabular}{lccccc}
\hline Nb of employees & $0-9$ & $10-19$ & $20-49$ & $50-249$ & $250-$ \\
\hline IFO & 0.06 & 0.08 & 0.2 & 0.42 & 0.23 \\
Manufacturing & 0.61 & 0.20 & 0.08 & 0.08 & 0.02 \\
\hline Source: IFO and Federal Statistical Office of Germany.
\end{tabular}

Table 2: Distribution of firms by sector (2013)

\begin{tabular}{lcccccccc}
\hline Sector & Food & Textile & Wood & Chemical & Metal & Electrical & Auto & Other \\
\hline IFO & 0.05 & 0.05 & 0.15 & 0.15 & 0.22 & 0.10 & 0.22 & 0.05 \\
Manufacturing & 0.12 & 0.03 & 0.08 & 0.15 & 0.25 & 0.11 & 0.22 & 0.05 \\
\hline
\end{tabular}

Source: IFO and Federal Statistical Office of Germany. 
The two main questions of interest concern expected and realized business activity. The survey provides both a discrete and a continuous measure for each variable. The discrete measure is available for the whole sample and tells us whether expected and realized business activity improves, remains about the same, or deteriorates. In 2005, the survey introduced a more continuous measure of these two variables on a 0-to-100 point scale. See Stangl (2009) for more details. Our translation from German of these questions is as follows:

- Expected Business Discrete. "Expectations for the next six months: Our business situation for product XY will (1) improve, (2) remain about the same, (3) deteriorate."

- Past Business Discrete. "The business situation for product XY compared to the previous month is: (1) better, (2) unchanged, (3) worse."

- Expected Business Continuous. "Expectations for the next six months: Our business situation for product XY will: (0) deteriorate, (50) remain about the same, (100) improve."

- Current Business Continuous. "Current situation: We assess the business situation for product XY as: (0) bad, (50) satisfactory, (100) good."

Since the Current Business Continuous is on level while all the other variables are changes, we compute a new variable that measures the change in business activity over the past month:

- Past Business Continuous. Equal to the difference between Current Business Continuous and Current Business Continuous of the previous month. We then rescale this variable on a scale of 0 to 100 , where (0) deteriorate, (50) remain about the same, (100) improve.

The next main variable of interest is the expectation error which we compute by taking the difference between the expected business and the future realized business. ${ }^{2}$ A positive error is thus associated with over-optimism and a negative error with over-pessimism. First, we need

\footnotetext{
${ }^{2}$ Bachmann et al. (2013) pioneered the computation of forecast errors using qualitative data.
} 
to match the temporal horizon of the forward-looking variable (6 months) and the backwardlooking variable (1 month). We do this by averaging the past business over the past 6 months. Let $x_{t}^{t-1}$ be the change in business activity over the previous month. The average change over the past 6 months is then: $x_{t}^{t-6}=\frac{1}{6} \sum_{\tau=0}^{5} x_{t-\tau}^{t-1}$. If any lag is missing, we set the new variable to missing. The expectation error is then the difference between the current expectation and the new variable that reports the change in business over the following six months. Let $y_{t}^{t+6}$ be the current expectation about the business at time $t+6$. The expectation error, $e_{t}^{t+6}$ is computed as the difference between $y_{t}^{t+6}$ and $x_{t}^{t-6}$. The measure ranges from -2 to 2 for the discrete variable and from -100 to 100 for the continuous variable.

Table 3 provides a summary of the characteristics of the main variables of interest, such as the temporal horizon of the questions, the years of availability and the range of values.

Table 3: Characteristics of variables.

\begin{tabular}{lccc}
\hline & Horizon & Data Range & Values \\
\hline Expected Business Discrete & 6 months & $1980-2014$ & $\{-1,0,1\}$ \\
Expected Business Continuous & 6 months & $2005-2014$ & {$[0,100]$} \\
Past Business Discrete & 1 month & $1980-2014$ & $\{-1,0,1\}$ \\
Past Business Continuous & 1 month & $2005-2014$ & {$[0,100]$} \\
Expectation Error Discrete & 6 months & $1980-2014$ & {$[-2,2]$} \\
Expectation Error Continuous & 6 months & $2005-2014$ & {$[-100,100]$} \\
\hline
\end{tabular}

Table 4 gives information about the distributions of firms' expectations and expectation errors. We have about 1.1 million firm-month observations for which at least one expectation error is available using the discrete variables and about 140,000 firm-month observations using the continuous variables. Using either the discrete or continuous measures, firms expect on average their future business to remain unchanged and report an unchanged past business activity. Furthermore, firms do not make expectation errors on average. This result holds both across time and firms and when computing the average expectation error within firm. 
Table 4: Summary statistics

\begin{tabular}{lcrrrrr}
\hline & $\mathrm{N}$ & mean & $\mathrm{p} 50$ & $\mathrm{sd}$ & $\mathrm{min}$ & $\max$ \\
\hline Across time and firms & & & & & & \\
\hline Expected Business Discrete & $1,528,800$ & -.047 & 0 & .60 & -1 & 1 \\
Past Business Discrete & $1,530,797$ & -.044 & 0 & .64 & -1 & 1 \\
Expectation Error Discrete & $1,126,982$ & -.004 & 0 & .58 & -2 & 2 \\
Expected Business Continuous & 173,336 & 52 & 51 & 17 & 0 & 100 \\
Past Business Continuous & 143,959 & 50 & 50 & 8 & 0 & 100 \\
Expectation Error Continuous & 143,753 & 2.1 & 1.5 & 19 & -100 & 100 \\
\hline Over time, by firm & & & & & & \\
\hline Expectation Error Discrete & 11,271 & .009 & -.003 & .27 & -1.8 & 1.9 \\
Expectation Error Continuous & 2,913 & 2.6 & 2.2 & 12.3 & -48.9 & 50 \\
\hline
\end{tabular}

Source: Dataset IBS IFO. Authors' computations.

\section{Over-Extrapolation?}

\subsection{Framework}

This section illustrates the concepts of extrapolation and over-extrapolation. We assume that firms have to predict the evolution of future business. Firms then over- extrapolate whenever they exaggerate the size of the effect of an explanatory variable on the evolution of their future business. Let us illustrate in the simple case when business change follows an AR(1) process

$$
y^{\prime}=\alpha y+\epsilon,
$$

where $y$ refers to business change, $y^{\prime}$ to next period's business change, $\alpha$ is a parameter, and $\epsilon$ is a white noise.

Firms forecast $y^{f}=\beta y$ and their expectation error is $y^{f}-y^{\prime}=\gamma y-\epsilon$, where $\gamma=\beta-\alpha$.

We are interested in estimating $\beta$ and $\gamma$. If $\beta$ is positive, firms extrapolate their recent experience and consider shocks to have some persistence. If $\beta$ is negative, then firms mean-revert and consider shocks to be short-lived.

If $\gamma$ is positive, then firms over-extrapolate. They consider shocks to be more persistent than they actually are. After their business has improved, firms expect their business to improve more 
Table 5: Individual experience

\begin{tabular}{|c|c|c|c|c|}
\hline VARIABLES & $\begin{array}{c}(1) \\
\text { Exp Business D }\end{array}$ & $\begin{array}{c}(2) \\
\text { Exp Error D }\end{array}$ & $\begin{array}{c}(3) \\
\text { Exp Business C }\end{array}$ & $\begin{array}{c}(4) \\
\text { Exp Error } C\end{array}$ \\
\hline Past Business & $\begin{array}{c}0.264^{* * *} \\
(0.00241)\end{array}$ & $\begin{array}{c}0.157^{* * *} \\
(0.00201)\end{array}$ & $\begin{array}{l}0.498^{* * *} \\
(0.0104)\end{array}$ & $\begin{array}{l}0.889^{* * * *} \\
(0.0120)\end{array}$ \\
\hline Constant & $\begin{array}{l}-0.0947^{* * *} \\
(0.00754)\end{array}$ & $\begin{array}{l}-0.00954 \\
(0.0117)\end{array}$ & $\begin{array}{l}28.62^{* * *} \\
(0.949)\end{array}$ & $\begin{array}{c}-43.21^{* * *} \\
(1.126)\end{array}$ \\
\hline Observations & $1,527,930$ & $1,126,510$ & 156,456 & 132,257 \\
\hline R-squared & 0.146 & 0.058 & 0.154 & 0.185 \\
\hline Number of firms & 11,271 & 11,271 & 3,005 & 2,870 \\
\hline FIRM FE & YES & YES & YES & YES \\
\hline TIME FE & YES & YES & YES & YES \\
\hline
\end{tabular}

than it actually will. By contrast, if $\gamma$ is negative, firms mean-revert too much. Finally, if $\gamma=0$, firms form unbiased forecasts.

\subsection{Baseline}

We first regress expectations and expectation errors on past business. We use the fixed effects estimator to control for firm-specific characteristics and also include time fixed effects to control for aggregate shocks. Standard errors are clustered at the firm level. ${ }^{3}$

Table 5 shows that firms are more optimistic about their future business when their business improved in the previous month. This result is highly significant and holds for both the discrete and the continuous measures. This suggests that firms consider shocks to their business to have some persistence.

The table also shows that expectation errors are positively correlated with past business.

\footnotetext{
${ }^{3}$ Since the data can only be analyzed on site and given the large number of observations, we save on computing time by using a linear fixed effects estimator in spite of having a discrete dependent variable. When estimating the effect of past business on expectation errors, past business is correlated with the past disturbances and the fixed effects estimator is thus biased. However, the bias can be considered small because we have a long time series. Nickell (1981) shows that the bias of the autoregressive coefficient $\alpha$ can be approximated by $-\frac{1+\alpha}{T-1}$, where $T$ is the number of periods. Bruno (2005) further shows that in the case of an unbalanced panel $T$ can be approximated by the average number of observations available per individual. In our data, we have on average $T=96$ observations available per firm. Assuming a true autoregressive coefficient between 0 and 1 yields a relatively small bias of between -0.01 and -0.02 .
} 
Again this result is significant and holds for both the discrete and the continuous measures. This suggests that firms exaggerate the persistence of the shocks. They become over-optimistic when their business has improved and over-pessimistic when it has deteriorated.

\subsection{Persistence}

We now study whether past business has persistent effects on expectations formed further in the future. We study the relationship between, on the one hand, expectations and expectation errors and, on the other hand, different lags of past business. If business experienced further in the past has an impact on expectations, this implies that firms extrapolate more strongly a streak of similar experience and thus that following a streak firms make larger mistakes. This also implies that a longer boom would make firms even more over-optimistic while a longer bust would make them more over-pessimistic. This also implies that firms would fail to initially recognize reversals. Finally, if some industries have more persistent shocks, they will also over-extrapolate more.

We run the same regression as above but controlling for 6 lags of past business. Table 6 shows the results. Firms also over-extrapolate business experienced further in the past. Both the discrete and continuous measures of expected business and expectation errors are positively and significantly correlated with all lags of past business.

\subsection{Asymmetric Effects}

Next, we study whether firms react asymmetrically to positive and negative experience. We now have two main regressors: positive past business which is equal to past business whenever it is positive and 0 otherwise (50 for the continuous variable); negative past business which is equal to past business whenever it is negative and 0 otherwise (50 for the continuous variable).

Table 7 suggests that both improvement and deterioration in past business are significantly correlated with expected business and expectation errors, for both the discrete and the continu- 
Table 6: Individual experience - persistence

\begin{tabular}{|c|c|c|c|c|}
\hline VARIABLES & $\begin{array}{c}(1) \\
\text { Exp Business D } \\
\end{array}$ & $\begin{array}{c}(2) \\
\text { Exp Error D }\end{array}$ & $\begin{array}{c}(3) \\
\text { Exp Business C }\end{array}$ & $\begin{array}{c}(4) \\
\text { Exp Error C } \\
\end{array}$ \\
\hline Past Business & $\begin{array}{c}0.229^{* * *} \\
(0.00219)\end{array}$ & $\begin{array}{c}0.140^{* * *} \\
(0.00191)\end{array}$ & $\begin{array}{l}0.742^{* * *} \\
(0.0178)\end{array}$ & $\begin{array}{l}1.270^{* * *} \\
(0.0210)\end{array}$ \\
\hline Past Business L1 & $\begin{array}{l}0.0740^{* * *} \\
(0.00124)\end{array}$ & $\begin{array}{l}0.0394^{* * *} \\
(0.00124)\end{array}$ & $\begin{array}{l}0.639^{* * *} \\
(0.0193)\end{array}$ & $\begin{array}{l}1.020^{* * *} \\
(0.0220)\end{array}$ \\
\hline Past Business L2 & $\begin{array}{l}0.0388^{* * *} \\
(0.00112)\end{array}$ & $\begin{array}{l}0.0212^{* * *} \\
(0.00109)\end{array}$ & $\begin{array}{l}0.505^{* * *} \\
(0.0191)\end{array}$ & $\begin{array}{l}0.809^{* * *} \\
(0.0201)\end{array}$ \\
\hline Past Business L3 & $\begin{array}{l}0.0262^{* * *} \\
(0.00110)\end{array}$ & $\begin{array}{l}0.0156^{* * *} \\
(0.00108)\end{array}$ & $\begin{array}{l}0.403^{* * *} \\
(0.0186)\end{array}$ & $\begin{array}{l}0.650^{* * *} \\
(0.0191)\end{array}$ \\
\hline Past Business L4 & $\begin{array}{l}0.0243^{* * *} \\
(0.00103)\end{array}$ & $\begin{array}{l}0.0129^{* * *} \\
(0.00107)\end{array}$ & $\begin{array}{l}0.314^{* * *} \\
(0.0166)\end{array}$ & $\begin{array}{l}0.513^{* * *} \\
(0.0167)\end{array}$ \\
\hline Past Business L5 & $\begin{array}{l}0.0293^{* * *} \\
(0.00105)\end{array}$ & $\begin{array}{c}0.00522^{* * *} \\
(0.00116)\end{array}$ & $\begin{array}{l}0.206^{* * *} \\
(0.0128)\end{array}$ & $\begin{array}{l}0.333^{* * *} \\
(0.0133)\end{array}$ \\
\hline Constant & $\begin{array}{c}-0.184^{* * *} \\
(0.0109)\end{array}$ & $\begin{array}{l}0.0424^{* *} \\
(0.0133)\end{array}$ & $\begin{array}{c}-84.87^{* * *} \\
(4.688)\end{array}$ & $\begin{array}{c}-226.1^{* * *} \\
(4.909)\end{array}$ \\
\hline Observations & $1,169,220$ & 962,444 & 111,700 & 97,057 \\
\hline R-squared & 0.158 & 0.062 & 0.225 & 0.297 \\
\hline Number of firms & 11,271 & 10,042 & 2,736 & 2,586 \\
\hline FIRM FE & YES & YES & YES & YES \\
\hline TIME FE & YES & YES & YES & YES \\
\hline
\end{tabular}


Table 7: Individual experience - asymmetry

\begin{tabular}{|c|c|c|c|c|}
\hline VARIABLES & $\begin{array}{c}(1) \\
\text { Exp Business D }\end{array}$ & $\begin{array}{c}(2) \\
\text { Exp Error D }\end{array}$ & $\begin{array}{c}(3) \\
\text { Exp Business C }\end{array}$ & $\begin{array}{c}(4) \\
\text { Exp Error } C\end{array}$ \\
\hline Pos Past Business & $\begin{array}{c}0.240^{* * *} \\
(0.00284)\end{array}$ & $\begin{array}{c}0.133^{* * *} \\
(0.00263)\end{array}$ & $\begin{array}{l}0.427^{* * *} \\
(0.0185)\end{array}$ & $\begin{array}{l}0.766^{* * *} \\
(0.0247)\end{array}$ \\
\hline Neg Past Business & $\begin{array}{l}-0.285^{* * *} \\
(0.00301)\end{array}$ & $\begin{array}{l}-0.178^{* * *} \\
(0.00276)\end{array}$ & $\begin{array}{l}0.565^{* * *} \\
(0.0211)\end{array}$ & $\begin{array}{l}1.007^{* * *} \\
(0.0267)\end{array}$ \\
\hline Constant & $\begin{array}{c}-0.0857^{* * *} \\
(0.00760)\end{array}$ & $\begin{array}{c}-0.000305 \\
(0.0117)\end{array}$ & $\begin{array}{l}4.175^{* *} \\
(1.304)\end{array}$ & $\begin{array}{c}-86.90^{* * *} \\
(1.537)\end{array}$ \\
\hline Observations & $1,527,930$ & $1,126,510$ & 156,456 & 132,257 \\
\hline R-squared & 0.146 & 0.059 & 0.155 & 0.185 \\
\hline Number of firms & 11,271 & 11,271 & 3,005 & 2,870 \\
\hline FIRM FE & YES & YES & YES & YES \\
\hline TIME FE & YES & YES & YES & YES \\
\hline Prob Equal Coef & 0.000 & 0.000 & 0.000 & 0.000 \\
\hline
\end{tabular}

ous measures. Furthermore, firms extrapolate a negative experience more than a positive one. This implies that firms are both over-pessimistic following a negative shock and over-optimistic following a positive shock. They also make larger mistakes following a negative shock than following a positive shock. The coefficients on positive past business and negative past business are significantly different at the $.1 \%$ level in all specifications, as shown in the last row of the table. A potential issue with the interpretation of these results is that for the discrete measure we only know the direction of the changes and not the size of the changes. If the unobserved size of the changes in past business are not symmetric, this could explain why we obtain different coefficients for positive and negative changes. Using the continuous measure, however, should alleviate this concern. It is thus reassuring that the relative difference between the coefficients on positive and negative past business remains roughly the same whether using the discrete or the continuous measures of expectations.

These results support the idea that individuals may suffer asymmetric losses when forming expectations (Elliott et al., 2008). Firms may indeed prefer to be a bit too conservative to avoid disappointment. Following an improving business, they become more optimistic but not 
too much to avoid disappointment. Our results suggest that disappointment aversion is not so strong that it overcomes the tendency to over-extrapolate. Following a negative shock, firms become more pessimistic not only because they expect the shock to be persistent but also because they want to avoid disappointment. These results can have consequences on the documented asymmetry of business cycles (Neftci, 1984; Sichel, 1993; McKay and Reis, 2008). If firms become more pessimistic following a negative shock than they become optimistic following a positive shock, then busts will be steeper than booms.

\subsection{Aggregate Shocks}

So far, we focused on the effect of shocks that affect individual firms. We now study whether changes in macroeconomic conditions - our proxy for aggregate shocks - have an effect alongside individual shocks. We run the same regression as above except that we replace the time fixed effects with aggregate variables. We focus on three variables that can potentially affect business activity: growth of industrial production, the long-term interest rate, and inflation (all from Eurostat).

Table 8 shows that firms become more optimistic following higher production growth and higher inflation. These effects are significant for both the discrete and continuous measures of expectations. The long-term interest rate does not have any significant effect on the discrete measure of expectations while it has a significant and positive effect on the continuous measure. The lagged interest rate, however, does have a positive and significant effect on the discrete measure of expectations (results not reported). The coefficient on individual past business retains its significance in both specifications, suggesting that firms extrapolate both individual and aggregate shocks.

The table also shows that the macroeconomic variables affect expectation errors. Firms extrapolate GDP growth, inflation, and the interest rate too much so that they make larger mistakes following a larger increase in these variables. These results are significant for both the discrete 
Table 8: Macroeconomic experience

\begin{tabular}{|c|c|c|c|c|}
\hline VARIABLES & $\begin{array}{c}(1) \\
\text { Exp Business D }\end{array}$ & $\begin{array}{c}(2) \\
\text { Exp Error D }\end{array}$ & $\begin{array}{c}(3) \\
\text { Exp Business C }\end{array}$ & $\begin{array}{c}(4) \\
\text { Exp Error C }\end{array}$ \\
\hline Past Business & $\begin{array}{c}0.274^{* * *} \\
(0.00294)\end{array}$ & $\begin{array}{c}0.151^{* * *} \\
(0.00262)\end{array}$ & $\begin{array}{l}0.499^{* * *} \\
(0.0103)\end{array}$ & $\begin{array}{l}0.856^{* * *} \\
(0.0122)\end{array}$ \\
\hline Production Growth & $\begin{array}{l}1.163^{* * *} \\
(0.0198)\end{array}$ & $\begin{array}{l}0.575^{* * *} \\
(0.0243)\end{array}$ & $\begin{array}{c}37.65^{* * *} \\
(1.032)\end{array}$ & $\begin{array}{c}36.50^{* * *} \\
(1.159)\end{array}$ \\
\hline Interest Rate & $\begin{array}{c}0.00161 \\
(0.00127)\end{array}$ & $\begin{array}{c}0.00658^{* * *} \\
(0.00140)\end{array}$ & $\begin{array}{c}0.754^{* * *} \\
(0.111)\end{array}$ & $\begin{array}{c}1.379^{* * *} \\
(0.128)\end{array}$ \\
\hline Inflation & $\begin{array}{c}4.038^{* * *} \\
(0.326)\end{array}$ & $\begin{array}{c}1.876^{* * *} \\
(0.370)\end{array}$ & $\begin{array}{c}316.4^{* * *} \\
(16.86)\end{array}$ & $\begin{array}{c}277.7^{* * *} \\
(21.79)\end{array}$ \\
\hline Constant & $\begin{array}{c}-0.0412^{* * *} \\
(0.00581)\end{array}$ & $\begin{array}{c}-0.0250^{* * *} \\
(0.00652)\end{array}$ & $\begin{array}{c}23.72^{* * *} \\
(0.601)\end{array}$ & $\begin{array}{c}-45.69^{* * *} \\
(0.709)\end{array}$ \\
\hline Observations & 839,430 & 615,316 & 156,456 & 132,257 \\
\hline R-squared & 0.122 & 0.034 & 0.121 & 0.127 \\
\hline Number of firms & 8,402 & 8,029 & 3,005 & 2,870 \\
\hline FIRM FE & YES & YES & YES & YES \\
\hline TIME FE & $\mathrm{NO}$ & $\mathrm{NO}$ & $\mathrm{NO}$ & $\mathrm{NO}$ \\
\hline
\end{tabular}

and continuous measures. Past business can still significantly predict expectation errors, suggesting that firms over-extrapolate both individual and aggregate shocks.

\section{Do firms anticipate reversals?}

So far, we have shown that firms over-extrapolate. Firms may thus fail to anticipate business cycle peaks or troughs. This is in contrast to a model of expectations in which firms would receive some signal about future business that would help them anticipate those reversals. We follow two approaches to investigate whether firms anticipate reversals or not. First, we study expectations around the peaks and troughs of business cycles. Second, we use the German reunification as a natural experiment. The fall of the Berlin wall provided west German manufacturers with a positive demand shock from East Germans. However, different industries were affected differently and we can thus compare whether their expectations anticipated these changes. 


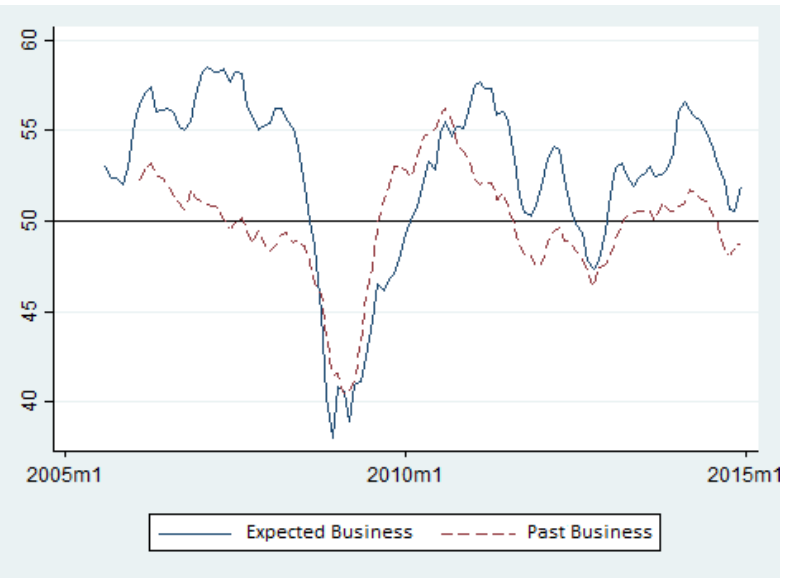

(a) Expected and past business

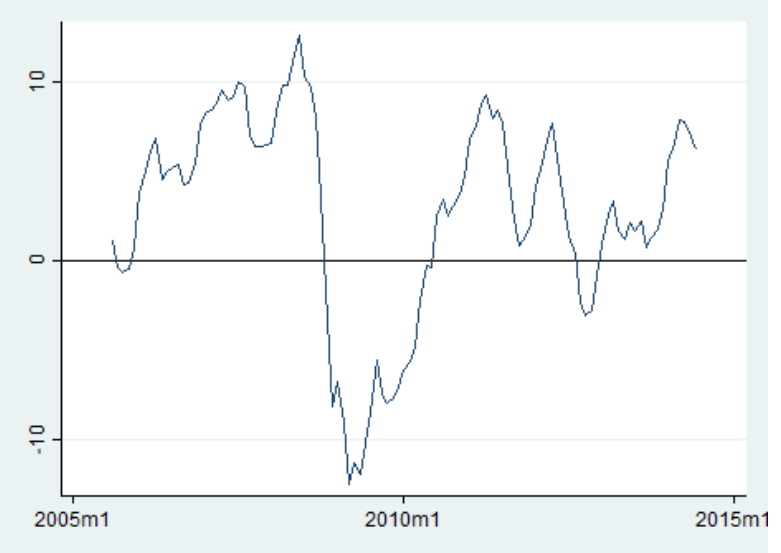

(b) Expectation errors

Figure 3: Evolution of continuous variables

\subsection{Peaks and Troughs}

Over-extrapolation may amplify business cycles if firms are systematically over-optimistic before crashes and over-pessimistic before recoveries. We look at expectations and expectation errors more specifically at business cycle peaks and troughs identified using our measure of reported business activity.

Figures 1 and 2 already suggest that expectations are unusually high before downturns and unusually low before recoveries. This conclusion is confirmed when we represent the continuous version of the same variables. Figure 3a shows the evolution of realized and expected business and Figure $3 b$ shows the evolution of expectation errors.

A regression analysis further confirms the eyeball analysis. We regress expected business and expectation errors on past business as well as on dummy variables indicating whether the current period is a peak or a trough, which we identify by smoothing the time-series and looking for turning points (two positive changes followed by two negative changes and vice-versa. The peak dates are: Feb. 1980, Apr. 1983, Apr. 1984, Apr. 1986, Dec. 1990, Apr. 1995, May 1998, Dec. 2000, Dec. 2004, Apr. 2008, Aug. 2011, Jun. 2014. The trough dates are: Feb 1983, Aug 1983, Dec. 1987, Dec. 1993, Oct. 1996, Jul. 1999, Sep. 2003, Jul. 2005, Aug. 2009, Feb. 2013, Dec. 2014. 
Table 9: Peaks and troughs.

\begin{tabular}{|c|c|c|c|c|}
\hline VARIABLES & $\begin{array}{c}(1) \\
\text { Exp Business D }\end{array}$ & $\begin{array}{c}(2) \\
\text { Exp Error D }\end{array}$ & $\begin{array}{c}(3) \\
\text { Exp Business C }\end{array}$ & $\begin{array}{c}(4) \\
\text { Exp Error C }\end{array}$ \\
\hline Past Business & $\begin{array}{l}0.291^{* * *} \\
(0.00254)\end{array}$ & $\begin{array}{l}0.163^{* * *} \\
(0.00203)\end{array}$ & $\begin{array}{l}0.527^{* * *} \\
(0.0107)\end{array}$ & $\begin{array}{l}0.886^{* * *} \\
(0.0121)\end{array}$ \\
\hline Peak & $\begin{array}{l}0.0623^{* * *} \\
(0.00234)\end{array}$ & $\begin{array}{l}0.0869^{* * *} \\
(0.00294)\end{array}$ & $\begin{array}{c}2.343^{* * *} \\
(0.156)\end{array}$ & $\begin{array}{c}3.912^{* * *} \\
(0.222)\end{array}$ \\
\hline Trough & $\begin{array}{l}0.0216^{* * *} \\
(0.00266)\end{array}$ & $\begin{array}{l}-0.0386^{* * *} \\
(0.00329)\end{array}$ & $\begin{array}{c}-2.417^{* * *} \\
(0.177)\end{array}$ & $\begin{array}{c}-4.048^{* * *} \\
(0.283)\end{array}$ \\
\hline Constant & $\begin{array}{l}-0.0369^{* * * *} \\
(0.000150)\end{array}$ & $\begin{array}{l}0.00169^{* * *} \\
(0.000144)\end{array}$ & $\begin{array}{c}25.48^{* * *} \\
(0.533)\end{array}$ & $\begin{array}{c}-42.26^{* * *} \\
(0.603)\end{array}$ \\
\hline Observations & $1,527,930$ & $1,126,510$ & 156,456 & 132,257 \\
\hline R-squared & 0.107 & 0.033 & 0.045 & 0.078 \\
\hline Number of firms & 11,271 & 11,271 & 3,005 & 2,870 \\
\hline FIRM FE & YES & YES & YES & YES \\
\hline TIME FE & $\mathrm{NO}$ & $\mathrm{NO}$ & $\mathrm{NO}$ & $\mathrm{NO}$ \\
\hline
\end{tabular}

The results we present are robust to using five rather than two consecutive periods to identify the turning points as well as to using a measure of peaks and troughs provided by the OECD (results not reported).

Table 9 shows the results. We find that on average firms are more optimistic than usual during peaks and more pessimistic than usual during troughs. As a result, peaks are also characterized by unusually over-optimistic firms and troughs by unusually over-pessimistic firms. This suggests that firms do not anticipate the upcoming reversals and that the extrapolation bias amplifies business cycles.

\subsection{German Reunification}

We more specifically study expectations during the German reunification because we know more about the types of shocks that affected firms during this period. The fall of the Berlin wall indeed enabled East Germans to import the often better West German products. Furthermore, different industries were affected differently. Industries producing necessity goods such as food 
experienced a boom. By contrast, industries producing more expensive and less necessary goods such as new cars benefited less or not at all from the reunification since East Germans could not afford them. East Germans were indeed initially poorer than West Germans and became even poorer after the reunification when the East German economy collapsed due to its low competitiveness. Merkl (2010) provides additional details on the economic situation during the German reunification.

The fall of the Berlin wall in November 1989 took place in a context of the start of a global recession such that all manufacturing sectors in West Germany were initially declining. We can then compare how necessity sectors such as food changed their expectations compared to more luxury sectors such as auto. Under extrapolative expectations, all sectors should expect things to keep worsening. However, it could be that different industries used different additional signals to forecast their different future. We can reasonably assume that firms did receive some signals since the life in both parts of the country gathered a lot of attention after the fall of the Berlin wall. Thus, some firms may have anticipated the higher demand for their product.

Figures 4 shows the evolution of past business, expected business, and expectation errors for the food and auto sectors around the fall of the Berlin wall. Figure 4a shows that past business in the food and car industries was decreasing at the same rate before the wall fell and started to diverge afterwards. Past business in the food industry started to sharply increase while past business in the car industry kept falling. The other industries, which we omit for clarity, fell in between these two extremes.

Figure $4 \mathrm{~b}$ shows that expectations in the food and car industry slightly decreased before the wall fell, thus following a similar trend as past business. After the fall, expectations started to diverge across sectors. The food industry became slightly more optimistic while the auto industry became more pessimistic.

We can then compare these trends with future realized business. Figure 4c shows the evolution of expectation errors. Both sectors form almost no expectation errors until a few months 


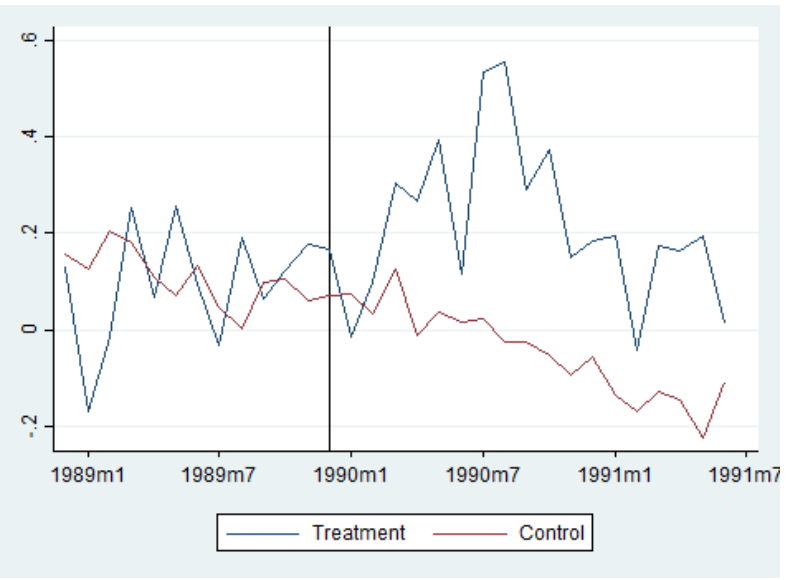

(a) Past business

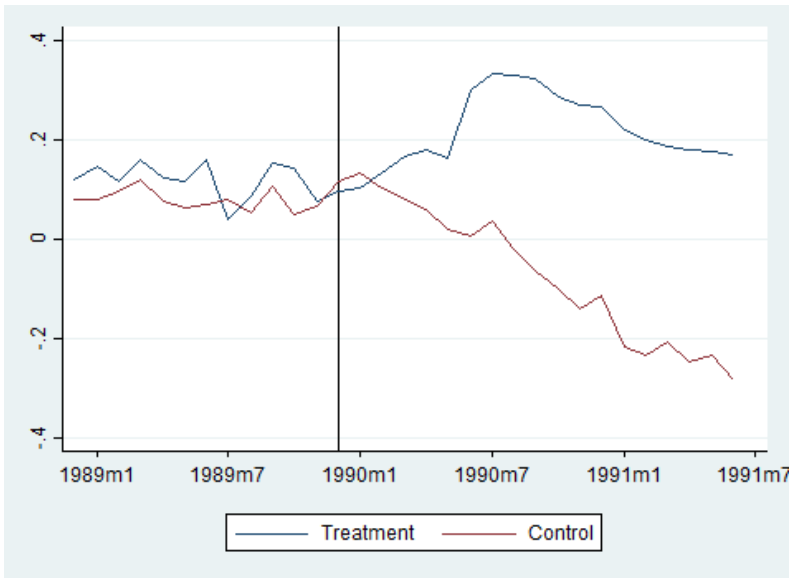

(b) Expected business

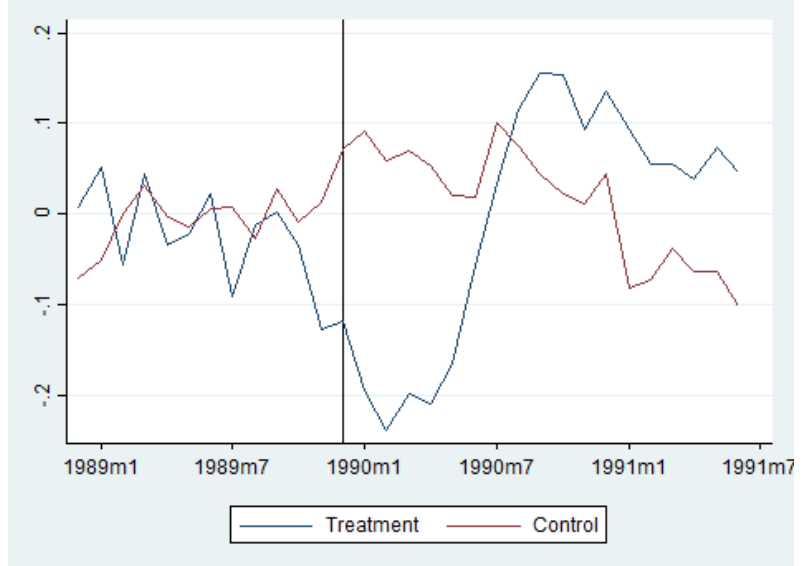

(c) Expectation error

Figure 4: German reunification

before the fall of the wall. The auto industry then formed correct expectations since it correctly anticipated that business will keep deteriorating. Firms in the food sector fail to see the upcoming spike in business which confirms the idea that neither the fall of the wall nor its consequences were expected at the time. These negative expectation errors survive even after the fall of the wall. By contrast, firms in the auto industry were a bit over-optimistic.

This evidence is consistent with each sector over-extrapolating its experience. Firms in the car industry simply extrapolate the initial negative trend and thus become more and more pessimistic. In this particular case, they actually under-extrapolate since they are over-optimistic. By contrast, the food industry also extrapolates the initial negative trend and thus misses the 
upcoming reversal. It fails to recognize the explosion in business until it is well under way. This reinforces the idea that firms do not just extrapolate their recent experience but also older experience. After several months of sharply increasing business activity in the food sector, expectations also start to increase sharply. Unfortunately, this is just when demand for food peaks and begins its descent. Firms in the food industry then shift from being over-pessimistic to being over-optimistic.

A regression analysis further confirms these observations. We study the effect of the fall of the Berlin wall on expected business and expectation errors of West German firms using a differencein-difference approach. The treatment group consists of the firms producing food that received a positive demand shock, and the control group of those producing cars that did not receive the demand shock. We estimate the following equation:

$$
y_{i, t}=\gamma_{i}+\sum_{\tau=1}^{18} \lambda_{k+\tau}+\sum_{\tau=1}^{18} \beta_{k+\tau} D_{i, k+\tau}+\epsilon_{i, t} .
$$

The dependent variable $y_{i, t}$ refers to either the expected business or the expectation error of the firm $i$ at time $t \in\{1988 m 12: 1991 m 5\} . \quad \lambda_{k+\tau}$ is a dummy equal to one for each month that follows the fall of the Berlin wall $k=1989 m 11 . \gamma_{i}$ is the treatment dummy equal to one if the firm belongs to the food sector. $D_{i, k+\tau}$ is a dummy equal to one if the firm belongs to the food sector and if the period follows the fall of the wall. The coefficient $\beta_{k+\tau}$ captures whether firms producing food changed their expectations and expectation errors in each month following the fall of the wall compared to firms producing cars.

We plot the monthly differences between the two groups in Figure 5. Panel 5a displays the differences in terms of expectations and Panel $5 \mathrm{~b}$ in terms of expectation errors. Right after the fall of the wall, the firms in the food sector are significantly more over-pessimistic than those in the car industry and they turn to be more over-optimistic a few months later. These results confirm that firms producing food failed to anticipate the positive shock to their demand. 


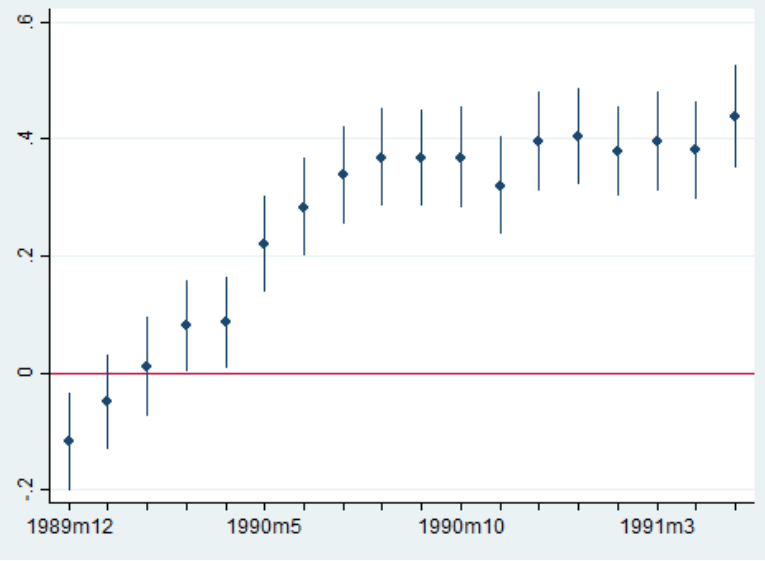

(a) Expected business

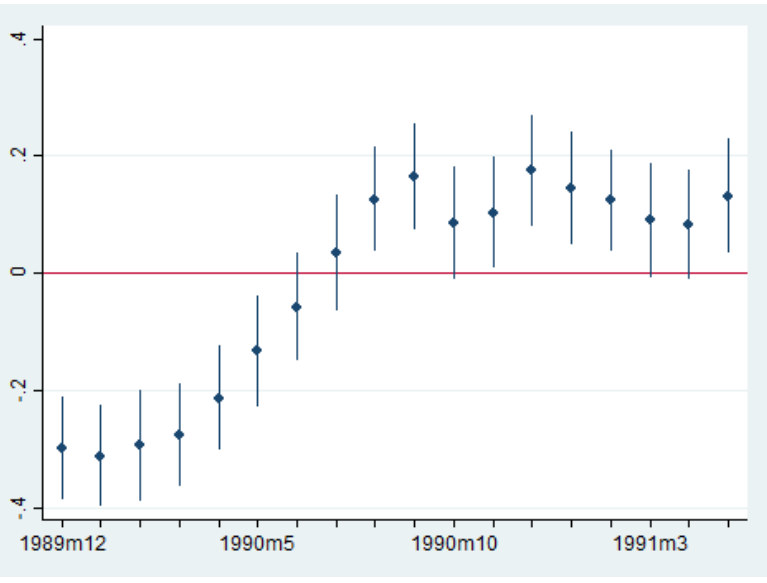

(b) Expectation error

Figure 5: Estimates of the difference in terms of expected business and expectation errors between firms producing food and those producing cars after the fall of the Berlin wall. The vertical bars represent the $95 \%$ confidence interval.

\section{Discussion}

\subsection{Supply vs Demand Shocks}

We also investigate whether the shocks that firms forecast are supply or demand shocks (or both).

To this end, we use another question from the survey that asks how firms expect their prices to evolve. The idea is that if a firm expects its business to improve, it faces a demand (supply) shock if at the same time it expects its prices to increase (decrease). Our translation from German of the question on price expectations is as follows:

- Price expectations. "Expectation for the next 3 months. Our domestic (net) prices for product $X Y$ - taking into account changes in conditions - will: (1) increase, (2) stay the same, (3) decrease."

When a firm expects its business activity to move in one direction, how often does it expect at the same time its prices to move in the same direction and how often in the opposite direction? Table 10 shows the results. We find that in the majority of cases firms that expect their business to move in one direction also expect their prices to move in the same direction. More precisely, firms that expect their business to deteriorate also expect their prices to decrease in $55 \%$ of the cases 
Table 10: Supply vs Demand

\begin{tabular}{lccc}
\hline & \multicolumn{3}{c}{ Expected Price } \\
& Lower & Unchanged & Higher \\
\cline { 2 - 4 } Expected Business & Freq & Freq & Freq \\
Lercent) & (Percent) & (Percent) \\
\hline \multirow{2}{*}{ Lower } & & & \\
& $50,588^{* * *}$ & $216,741^{* * *}$ & $43,671^{* * *}$ \\
Unchanged & $(54.79)$ & $(18.66)$ & $(16.02)$ \\
& $35,162^{* * *}$ & $773,341^{* * *}$ & $168,548^{* * *}$ \\
Higher & $(38.08)$ & $(66.56)$ & $(61.82)$ \\
& $6,584^{* * *}$ & $171,752^{* * *}$ & $60,427^{* * *}$ \\
& $(7.131)$ & $(14.78)$ & $(22.16)$ \\
\hline
\end{tabular}

while they only expect their prices to increase at the same time in $16 \%$ of the cases. When firms expect their business to improve, they expect their prices to also increase in $22 \%$ of the cases and to decrease in $7 \%$ of the cases. This suggests that when firms think about their future business activity, demand conditions seem to play a more important role than supply conditions. This result is consistent with Bachmann and Zorn (2016), who show that a large part of fluctuations in aggregate investment can be attributed to demand shocks.

\subsection{Are expectation errors costly?}

When firms form the wrong expectations about their future business conditions, they may fail to maximize their profit because of inefficient employment or investment decisions. For example, if firms hire too many employees or invest too much, they will have higher costs and thus lower profits. They will also produce too much and increase their inventories. By contrast, it they fail to hire enough employees or do not invest enough, they may miss on some profits and will have lower inventories. Note that their profits may still increase due to the lower costs.

To study the costs of expectation errors, we use two additional questions from the survey in which firms report on the current situation of their inventories and profits. Our translation from German of these questions is as follows:

- Profit "We currently assess the earnings situation of our company - as measured by the 
Table 11: Costs of Expectation Errors

\begin{tabular}{|c|c|c|c|c|}
\hline & \multicolumn{2}{|c|}{ Discrete } & \multicolumn{2}{|c|}{ Continous } \\
\hline & (1) & (2) & (3) & $(4)$ \\
\hline & Inventories & Profit & Inventories & Profit \\
\hline \multirow[t]{2}{*}{ Neg Exp Error L6, } & $-0.00992^{* *}$ & $0.0554^{* * *}$ & $-0.000938^{* *}$ & $0.00596^{* * *}$ \\
\hline & $(0.00357)$ & $(0.00949)$ & $(0.000309)$ & $(0.000479)$ \\
\hline \multirow[t]{2}{*}{ Pos Exp Error L6, } & $0.101^{* * *}$ & $-0.115^{* * *}$ & $0.00186^{* * *}$ & 0.000755 \\
\hline & $(0.00366)$ & $(0.00991)$ & $(0.000272)$ & $(0.000498)$ \\
\hline \multirow[t]{2}{*}{ Constant } & $0.181^{* * *}$ & $-0.133^{* * *}$ & $0.0859 * * *$ & $-0.0399 * * *$ \\
\hline & $(0.00123)$ & $(0.00358)$ & $(0.00303)$ & $(0.00536)$ \\
\hline Observations & 746,795 & 45,425 & 97,723 & 23,038 \\
\hline R-squared & 0.005 & 0.004 & 0.002 & 0.013 \\
\hline Number of plantnum & 9,602 & 4,950 & 2,464 & 2,773 \\
\hline FIRM FE & YES & YES & YES & YES \\
\hline TIME FE & $\mathrm{NO}$ & $\mathrm{NO}$ & $\mathrm{NO}$ & $\mathrm{NO}$ \\
\hline
\end{tabular}

operating profit from ordinary activities - as: (1) good, (2) satisfactory, (3) bad."

- Inventories "Stock of finished goods. Our current stock of unsold finished goods of product $X Y$ for now corresponds - in weeks of current production levels - to: 0 ; less than .5; .5 ; 1 ; more than 6."

We then regress profits and inventories on past expectation errors. Since our measure of expectation error materializes 6 months later, we use the sixth lag of expectation error. We distinguish between positive and negative errors. A positive (negative) expectation error is equal to the expectation error whenever it is positive (negative) and 0 otherwise. Table 11 shows the results. As expected, we find that overoptimistic firms subsequently report larger inventories and lower profits. By contrast, overpessimistic firms report lower inventories and higher profits. While the higher profits sound like a good thing, the lower inventories signal that firms may have missed on even higher profits. Overall, this suggests that expectation errors are costly for firms. 


\subsection{Learning}

If expectation errors are costly, firms may try to reduce their extrapolation bias over time. As a result, older firms may have more experience and learn over time how to make more accurate forecasts. Furthermore, larger firms may be able to spend more resources on forecasting than smaller firms. We should thus expect a smaller expectation bias for older and larger firms. This would imply that when we regress expectation errors on the interaction between past business and age or size, the overall coefficient on past business should be closer to 0 for older and larger firms.

We first need a measure of how old each firm is. Ideally, we would like to know when the firm was created. However, the survey does not provide this information and we cannot retrieve it due to confidentiality. As an alternative, we measure age by proxying the birth rate of the firm as the first time it participated to the survey. Our measure underestimates the true age of the firm because the firm may have been created before the survey started or before it first started to answer the survey. Furthermore, this is more likely to be true for older firms, especially firms that were created before the survey started. If we find an effect of age on expectations, we will thus overestimate the strength of this effect (whether positive or negative).

We regress the two measures of expectation errors on past business, the measure of age (in years) and their interaction. Table 12 shows the results. We find that the impact of past business on expectation errors decreases with age. According to both estimates, it would take about 7 centuries for the extrapolation bias to be eliminated. This suggests that there is some learning going on but it is quite slow. Note that since we probably overestimate the strength of the effect of age, learning may be even slower.

We also look at the impact of size on expectation errors where we would expect firms with more employees to suffer less from the extrapolation bias. Participants to the survey can provide the number of employees working in the firm. We use this variable to create an indicator variable 
Table 12: Learning

\begin{tabular}{|c|c|c|}
\hline VARIABLES & $\begin{array}{c}(1) \\
\text { Exp Error D }\end{array}$ & $\begin{array}{c}(2) \\
\text { Exp Error } C\end{array}$ \\
\hline Past Business & $\begin{array}{c}0.190^{* * *} \\
(0.00259)\end{array}$ & $\begin{array}{l}0.738^{* * *} \\
(0.0201)\end{array}$ \\
\hline Age & $\begin{array}{c}0.000768^{* * *} \\
(4.49 \mathrm{e}-05)\end{array}$ & $\begin{array}{c}-0.0791^{* *} \\
(0.0262)\end{array}$ \\
\hline Past Business*Age & $\begin{array}{c}-0.000258^{* * *} \\
(1.99 \mathrm{e}-05)\end{array}$ & $\begin{array}{c}0.000576 \\
(0.000503)\end{array}$ \\
\hline Constant & $\begin{array}{l}-0.403^{* * *} \\
(0.00561)\end{array}$ & $\begin{array}{c}-32.87^{* * *} \\
(1.035)\end{array}$ \\
\hline Observations & $1,126,510$ & 121,046 \\
\hline R-squared & 0.034 & 0.157 \\
\hline Number of plantnum & 11,271 & 2,756 \\
\hline FIRM FE & YES & YES \\
\hline TIME FE & NO & $\mathrm{NO}$ \\
\hline
\end{tabular}

that is equal to 0 if the firm has between 0 and 10 employees, 1 if the firm has between 11 and 20 employees, 2 between 21 and 50, 3 between 51 and 250, and 4 if it has more than 251 employees.

We then regress expectation errors on past business, size category, and their interaction. Table 13 shows the results. As expected, large firms (more than 250 employees) have an extrapolation bias that is 10 to $25 \%$ lower than small firms (less than 10 employees). Since our sample underrepresents small firms and over-represents large firms, this implies that our results on overextrapolation are conservative.

\section{Conclusion}

This paper investigates the expectation formation process of firms using survey data from the German manufacturing sector. We first document that firms extrapolate their experience too much. Firms exaggerate the persistence of shocks and end up making predictable expectation errors. Following an improvement in their business, for example, firms become in retrospective over-optimistic. We show that this result holds for both individual and aggregate shocks. Also, 
Table 13: Large vs small

\begin{tabular}{|c|c|c|}
\hline VARIABLES & $\begin{array}{c}(1) \\
\text { Exp Error D }\end{array}$ & $\begin{array}{c}(2) \\
\text { Exp Error C }\end{array}$ \\
\hline Past Business & $\begin{array}{l}0.175^{* * *} \\
(0.00589)\end{array}$ & $\begin{array}{l}0.945^{* * *} \\
(0.0400)\end{array}$ \\
\hline Size & $\begin{array}{c}-0.000433 \\
(0.00510)\end{array}$ & $\begin{array}{c}2.948^{* * *} \\
(0.764)\end{array}$ \\
\hline Past Business*Size & $\begin{array}{l}-0.00417^{*} \\
(0.00189)\end{array}$ & $\begin{array}{c}-0.0649^{* * *} \\
(0.0132)\end{array}$ \\
\hline Constant & $\begin{array}{c}-0.322^{* * *} \\
(0.0154)\end{array}$ & $\begin{array}{c}-44.37^{* * *} \\
(2.272)\end{array}$ \\
\hline Observations & $1,109,688$ & 121,046 \\
\hline R-squared & 0.033 & 0.154 \\
\hline Number of plantnum & 10,390 & 2,756 \\
\hline FIRM FE & YES & YES \\
\hline TIME FE & $\mathrm{NO}$ & $\mathrm{NO}$ \\
\hline
\end{tabular}

firms seem to over-extrapolate negative shocks more than positive ones thus potentially slowing down recoveries and precipitating crashes. Finally, firms over-extrapolate not just their recent experience but also older experience. This implies that when a reversal in their business takes place, firms take time to incorporate it in their expectations.

A potential implication of over-extrapolation is that firms fail to anticipate reversals in business conditions and thus that business cycles are amplified. We first show that during peaks and troughs firms are, respectively, unusually optimistic and pessimistic. This is at odds with a model in which firms would receive some signals about their future business activity. When studying the German reunification period, we find that West German firms extrapolated the initial negative trend and, as a result, that the firms that subsequently experienced a positive demand shock failed to anticipate this reversal.

Finally, we show that the shocks that firms forecast are mostly demand shocks since firms tend to expect prices to move in the same direction as their expected business activity. We also show that expectation errors are costly because they affect profits and inventories. Finally, larger 
and older firms have a slightly smaller extrapolation bias, consistent with the idea that firms can spend time and resources to form more accurate expectations.

Our work extends the research that documents the existence of an extrapolation bias in the expectation formation process. Most of this work has so far focused on financial markets and forecasts about aggregate variables. We offer additional evidence suggesting that the extrapolation bias is a pervasive phenomenon, that can have consequences on both the forecaster and the economy at large.

\section{References}

Abberger, K. and Wohlrabe, K. (2006). Einige prognoseeigenschaften des ifo geschäftsklimas-ein überblick über die neuere wissenschaftliche literatur. ifo Schnelldienst, 59(46-48):19.

Andrade, P. and Le Bihan, H. (2013). Inattentive professional forecasters. Journal of Monetary Economics, 60(8):967-982.

Asparouhova, E., Hertzel, M., and Lemmon, M. (2009). Inference from streaks in random outcomes: Experimental evidence on beliefs in regime shifting and the law of small numbers. Management Science, 55(11):1766-1782.

Bachmann, R. and Elstner, S. (2015). Firm optimism and pessimism. European Economic Review, 79:297-325.

Bachmann, R., Steffen, and Sims, E. R. (2013). Uncertainty and economic activity: Evidence from business survey data. American Economic Journal: Macroeconomics, 5(2):217-249.

Bachmann, R. and Zorn, P. (2016). What Drives Aggregate Investment? Evidence from German Survey Data. Working paper.

Barberis, N., Shleifer, A., and Vishny, R. (1998). A model of investor sentiment. Journal of financial economics, 49(3):307-343.

Beshears, J., Choi, J. J., Fuster, A., Laibson, D., Madrian, B. C., et al. (2013). What goes up must come down? experimental evidence on intuitive forecasting. American Economic Review, 103(3):570-74.

Bruno, G. S. (2005). Approximating the bias of the lsdv estimator for dynamic unbalanced panel data models. Economics Letters, 87(3):361 - 366.

Buchheim, L. and Link, S. (2017). Do firms expect disaggregate shocks? Working paper.

Coibion, O. and Gorodnichenko, Y. (2012). What can survey forecasts tell us about information rigidities? Journal of Political Economy, 120(1):116-159.

Coibion, O. and Gorodnichenko, Y. (2015). Information rigidity and the expectations formation process: A simple framework and new facts. The American Economic Review, 105(8):2644-2678. 
Coibion, O., Gorodnichenko, Y., and Kumar, S. (2015). How Do Firms Form Their Expectations? New Survey Evidence. Working paper.

Elliott, G., Komunjer, I., and Timmermann, A. (2008). Biases in macroeconomic forecasts: irrationality or asymmetric loss? Journal of the European Economic Association, 6(1):122-157.

Frydman, C. and Nave, G. (2016). Extrapolative beliefs in perceptual and economic decisions: Evidence of a common mechanism. Management Science.

Gennaioli, N., Ma, Y., and Shleifer, A. (2015). Expectations and investment. In NBER Macroeconomics Annual 2015, Volume 30. University of Chicago Press.

Gilovich, T., Vallone, R., and Tversky, A. (1985). The hot hand in basketball: On the misperception of random sequences. Cognitive psychology, 17(3):295-314.

Greenwood, R. and Shleifer, A. (2014). Expectations of returns and expected returns. Review of Financial Studies, 27(3):714-746.

Haruvy, E., Lahav, Y., and Noussair, C. N. (2007). Traders' expectations in asset markets: experimental evidence. The American Economic Review, 97(5):1901-1920.

Hommes, C., Sonnemans, J., Tuinstra, J., and Van De Velden, H. (2008). Expectations and bubbles in asset pricing experiments. Journal of Economic Behavior \& Organization, 67(1):116-133.

Kahneman, D. (2011). Thinking, fast and slow. Macmillan.

Malmendier, U. and Nagel, S. (2011). Depression babies: Do macroeconomic experiences affect risk taking? The Quarterly Journal of Economics, 126(1):373-416.

Manski, C. F. (2004). Measuring expectations. Econometrica, 72(5):1329-1376.

Massenot, B. and Pettinicchi, Y. (2017). Can Households See into the Future? Survey Evidence from the Netherlands. Working Paper.

McKay, A. and Reis, R. (2008). The brevity and violence of contractions and expansions. Journal of Monetary Economics, 55(4):738-751.

Merkl, P. H. (2010). German unification in the European context. Penn State Press.

Neftci, S. N. (1984). Are economic time series asymmetric over the business cycle? The Journal of Political Economy, 92(2):307-328.

Nickell, S. (1981). Biases in dynamic models with fixed effects. Econometrica: Journal of the Econometric Society, pages 1417-1426.

Pesaran, M. H. and Weale, M. (2006). Survey expectations. Handbook of economic forecasting, 1:715-776.

Piazzesi, M. and Schneider, M. (2009). Momentum traders in the housing market: Survey evidence and a search model. American Economic Review, 99(2):406-11.

Rabin, M. (2002). Inference by believers in the law of small numbers. The Quarterly Journal of Economics, 117(3):775-816. 
Rabin, M. and Vayanos, D. (2010). The gambler's and hot-hand fallacies: Theory and applications. The Review of Economic Studies, 77(2):730-778.

Sichel, D. E. (1993). Business cycle asymmetry: a deeper look. Economic Inquiry, 31(2):224-236.

Stangl, A. (2009). Essays on the Measurement of Economic Expectations. Munich Dissertations in Economics 9823, University of Munich, Department of Economics.

Tortorice, D. L. (2012). Unemployment expectations and the business cycle. The BE Journal of Macroeconomics, 12(1).

Triebs, T. P. and Tumlinson, J. (2016). Learning Capitalism the Hard Way - Evidence from German Reunification. Working paper.

Tversky, A. and Kahneman, D. (1974). Judgment under uncertainty: Heuristics and biases. science, 185(4157):1124-1131.

Vissing-Jorgensen, A. (2004). Perspectives on behavioral finance: Does" irrationality" disappear with wealth? evidence from expectations and actions. In NBER Macroeconomics Annual 2003, Volume 18, pages 139-208. The MIT Press. 


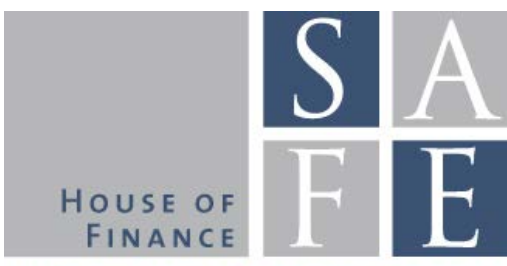

WORKING PAPER SERIES

\section{Recent Issues}

No. 186 Nicole Branger, Paulo Rodrigues, Christian Schlag

No. 185 Patrick Grüning

No. 184 Tobias Tröger

No. 183 Joost Driessen, Theo E. Nijman, Zorka Simon

No. 182 Mario Bellia, Loriana Pelizzon, Marti G. Subrahmanyam, Jun Uno, Darya Yuferova

No. 181 Holger Kraft, Farina Weiss

No. 180 Tobias H. Tröger

No. 179 Tobias H. Tröger

No. 178 Matthias Goldmann

No. 177 Michael Donadelli, Marcus Jüppner, Max Riedel, Christian Schlag

No. 176 Giuliano Curatola, Ilya Dergunov

No. 175 Reint Gropp, Deyan Radev
Level and Slope of Volatility Smiles in LongRun Risk Models

Heterogeneity in the Internationalization of R\&D: Implications for Anomalies in Finance and Macroeconomics

Remarks on the German Regulation of Crowdfunding

The Missing Piece of the Puzzle: Liquidity Premiums in Inflation-Indexed Markets

Coming Early to the Party

Consumption-Portfolio Choice with Preferences for Cash

Why MREL Won't Help Much

Too Complex to Work: A Critical Assessment of the Bail-in Tool under the European Bank Recovery and Resolution Regime

United in Diversity? The Relationship between Monetary Policy and Banking Supervision in the Banking Union

Temperature Shocks and Welfare Costs

International Capital Markets with TimeVarying Preferences

International Banking Conglomerates and the Transmission of Lending Shocks across Borders 